\title{
South Moravian Mobility Study \\ Basic Findings and Comparison with German Data
}

\author{
P. Malina*, P. Koư̌il, P. Šenk \\ Transport Research Centre, Brno, Czech Republic, \\ *Corresponding author: petr.malina@cdv.cz
}

DOI: 10.2478/trans-2014-0006

\begin{abstract}
Transport planning in the Czech Republic faces the problem of a lack of data on travel behaviour. The paper deals with the usability of foreign travel behaviour data for transport modelling in the Czech Republic. The authors present their findings on the example of a comparison between the results from the data analysis of a travel demand survey in the South Moravian region, which was performed in 2013 on the sample of 1000 households and a German survey Mobilität in Deutschland.
\end{abstract}

KEY WORDS: Travel behaviour, South Moravian region, transport planning.

\section{THE FIRST REGIONAL MOBILITY SURVEY IN THE CZECH REPUBLIC}

The point of transport planning is to secure sustainable transport development and to make transport accessible to the whole community. Data analysis of travel behaviour is a necessary prerequisite for high-quality transport planning, as well as a base for high-quality transport models. However, in the Czech Republic, the lack of coherent travel behaviour data is still apparent, with the exception of a few individual surveys, which nevertheless were carried out only on the level of municipalities (Braun Kohlová et al., 2007). The first large-scale survey performed on the regional level is the travel behaviour survey in the South Moravian Region ${ }^{1}$. This survey was carried out within a project involving cross-border cooperation with Austria called Transport Model AT-CZ in 2013. The data provided by this survey were used to compile and parameterize the transport model of the South Moravian Region (hereinafter SMR), but there are more possibilities for its utilization.

In the area of transport modelling alone, there is a wide scope of possible uses of travel behaviour data. With regard to the traditional four-step approach to transport modelling, a wide scope of data use is apparent when modelling travel demand. For the purposes of the Transport Model AT-CZ, three basic travel demand sub-models were created. For the trip generation model, the data were used to derive the number of trips to previously defined areas (zones), divided according to the trip purpose. The survey data were used to compile a multinomial logit model of trip distribution and travel mode choice. From all survey data, the realized trip destinations by the used means of transport were considered. The data could possibly be used for predictions related to ownership of specific means of transport, driver's

\footnotetext{
${ }^{1}$ Largest travel behaviour survey in the Czech Republic - Travel behaviour of residents and visitors of Prague and Prague metropolitan area - covers the area of the city of Prague and two surrounding districts.
} 
licenses or discount tickets for public transport (Cinzia, 2010; de Jong et al., 2004). The data also offer the possibility of validating individual submodels, provided that they were not used for compilation and parameterization of the model.

Besides transport modelling, the data can be used to study patterns of the spatio-temporal behaviour typical of a certain group of people (e. g. students, retired people) (Yu \& Shaw, 2004). For example, it is possible to estimate at what time a certain group of people would travel for a specific reason. Information of this kind relates to the areas of network analyses and location tasks (Schönfelder \& Axhausen, 2010), which can be utilized in social sciences, urbanism, economy or even marketing (e. g. where to place a parking lot, an ATM or advertisement, etc.).

If no data about travel behaviour are available, the companies, institutions and experts in the area of transport modelling do not have any other choice but to use data from other countries for the purposes of travel demand modelling. This approach was chosen in the case of building the Czech national model (Vachtl et al., 2012).

The problem of travel behaviour data transferability from one region to another is discussed in extensive research work. There are statistical methods to simulate new data from more extensive surveys, for example from national to regional level. Limitation is that there is a need for very detailed demographic and land-use data of a modelled area (Stopher et al., 2004). Travel behaviour data transferability from one region to another is another research topic. In that case, data have similar structure but there are certain variables for which mean and standard deviation values differ across different regions (U.S. DOT Volpe National Transportation Systems Center, 2005; Mohammadian \& Zhang, 2007). Additionally, by using various statistical methods, the transferability of travel demand models itself is researched. Nevertheless, after using these statistical tests, there is no guarantee of the goodness of transferred models (Karasmaa, 2003).

The goal of this paper is to compare mean values of basic variables of travel behaviour data such as trip rates or mode shares to see how much they can differ across foreign countries. The comparison is carried out for data analysis results from the SMR and from the German survey Mobilität in Deutschland (Follmer et al., 2010).

\section{PEOPLE IN THE SMR TRAVEL LESS THAN PEOPLE IN GERMANY}

The travel behaviour survey in the SMR was carried out in May and June 2013. It involved 1,000 households sampled by a method of random stratified selection. To secure comparability of the data with the neighbouring cross-border areas, the KOMOD methodology was selected for the survey, since it is used for the standardization of the data not only in the original area, but also in Austria and recently in Slovakia as well. The KOMOD (Fellendorf et al., 2011) methodology unifies indicators of travel behaviour and defines the methods of selecting samples and collecting data, as well as assuring data quality. In the survey, the households were asked in person about their size, income and which means of transport they owned. Basic socio-demographic characteristics were established for each household member. The interviewed household members listed all the trips realized on a certain, previously chosen working day. Information about these trips included duration, distance travelled, used means of transport and purpose of the trip.

Below, the findings of the South-Moravian survey are compared to the result of the nationwide German travel behaviour survey Mobilität in Deutschland (MiD). This survey was carried out for the first time in 2002; however, it is a continuation of earlier mobility surveys from 1976, 1982 and 1989 (Institut für Verkehrs- und Infrastrukturforschung $\mathrm{GmbH}, 2009)$. The data in the comparison originate in the latest version of MiD from 2008. 
The methodology used in the SMR shares a lot of features, mainly concerning the researched attributes of the households, persons, trips and means of transport. However, MiD differs in the used data collection method (phone interviews) and mainly in the duration of the survey - the data were collected over the course of a whole year, February 2008 through March 2009. To compare the results of both surveys, only the data for the given working day were used. The basic survey sample consisted of 25,000 households; a total of 50,000 households was reached by including other regional samples.

It is apparent from the survey in Germany that travel behaviour differs across individual regions - in Germany across individual states. For the purposes of comparison with the SMR, the state of Thuringia was chosen, since its basic demographic and geographical characteristics most resemble those of the SMR.

The analysis of the basic survey output revealed that a large percentage of people (18.8\%) did not travel at all during the given day. In the German survey, this value is approximately $10 \%$ (it is 10.5 in Thuringia). A basic mobility attribute is the so-called "trip rate", standing for the number of trips per person per day. In the SMR, this value is 2.2; while in German Thuringia, it is 3.3. In other surveys, for comparison, e.g. in the USA or elsewhere in Germany, this value was almost always higher than 3. This value is influenced by a high percentage of people who did not travel at all on the given day; nevertheless, similar results (between 1.7 and 2.9) like in the SMR were provided by surveys carried out in various municipalities in the Czech Republic concerning the indicator A.3 "Mobility and local transport of passengers." (Timur, 2014). It should be noted that the methodology in these indicator A.3 Czech surveys is drastically simplified compared to the methodology used in the SMR survey.

The trip purposes analysis in the SMR revealed that the main reason people travel was for work and business trips (35\% of all trips). In Thuringia, Germany, the work trips accounted for only $23 \%$ of all travel purposes and the most dominant purpose there was leisure activities (30.4\%). While in the SMR, trips for education and work reasons made up almost half of all the trips (47.6\%), in Thuringia, it is only $27.9 \%$. The comparison suggests that Germans travel much more often in their free time. The results of the trip purpose analysis are summarized in Table 1.

Table 1: Comparison of trip purposes in the SMR, Thuringia and Germany.

\begin{tabular}{|l|r|r|r|}
\hline Trip purpose & \multicolumn{1}{|c|}{ SMR } & Thuringia & Germany \\
\hline Work and business travel & $35.0 \%$ & $23.0 \%$ & $20.3 \%$ \\
\hline Education & $12.6 \%$ & $4.9 \%$ & $6.2 \%$ \\
\hline Shopping & $17.8 \%$ & $20.5 \%$ & $20.5 \%$ \\
\hline Leisure time activities & $17.2 \%$ & $30.4 \%$ & $32.4 \%$ \\
\hline $\begin{array}{l}\text { Other (e. g. accompanying people, visiting } \\
\text { a doctor, an office, etc.) }\end{array}$ & $17.5 \%$ & $21.2 \%$ & $20.3 \%$ \\
\hline
\end{tabular}

There is also an apparent difference in the percentage of the used means of transport. While in Germany, individual car transportation is by far the most prominent transportation method (with 56\%), in the SMR cars (39.1\%) are rivalled by public transport (26.2\%). The comparison shows that the use of non-motorised means of transport in the SMR and Germany is similar, with biking and walking combined making up 34\%. All results are summarized in Table 2. 
Table 2: Comparison of means of transport / travel modes in the SMR, Thuringia and Germany.

\begin{tabular}{|l|r|r|r|}
\hline Means of transport & \multicolumn{1}{|c|}{ SMR } & Thuringia & Germany \\
\hline Walking & $26.8 \%$ & $30.0 \%$ & $23.7 \%$ \\
\hline Bicycle & $7.2 \%$ & $3.7 \%$ & $10.0 \%$ \\
\hline Individual car transportation & $39.1 \%$ & $55.9 \%$ & $56.0 \%$ \\
\hline Public transport & $26.2 \%$ & $5.9 \%$ & $7.2 \%$ \\
\hline Motorbike & $0.4 \%$ & $0.4 \%$ & $0.5 \%$ \\
\hline Other & $0.3 \%$ & $4.1 \%$ & $2.5 \%$ \\
\hline
\end{tabular}

\section{DISCUSSION AND CONCLUSION}

In the Czech Republic, only a few travel behaviour surveys have been carried out, and only at the municipal level. The first regional travel behaviour survey was carried out in the SMR in 2013. The options for survey data utilization range from socio-demographic analyses to network and location tasks (analysis of the spatio-temporal behaviour patterns). Nevertheless, its main purpose lies in the field of traffic modelling.

When producing the current models, travel behaviour data are often taken from foreign countries. The difference between mean values of basic characteristics of mobility in the SMR and in Germany, or rather Thuringia, demonstrates that the use of foreign travel behaviour data for Czech conditions would be unsuitable. The survey revealed that the inhabitants in the SMR travel generally much less and, on average, take 2.2 trips a day, while the inhabitants of Germany average more than three trips a day. In addition, the comparison of the results of both surveys suggests that there are significant differences both in the purposes of these trips, and in the means of transport used.

All these conclusions support the notion that even mean values of basic travel behaviour differs between individual states and regions. Hence it is not probably appropriate to generalize the data analysis results from the SMR and apply them to other regions of the Czech Republic. A reliable data source for compiling high-quality transport models should be a survey of travel behaviour of a region in question.

If the field of transport planning in the Czech Republic is to achieve more recognition, and not only within its own borders, it is necessary to carry out travel behaviour surveys on regional as well as national levels. To support this step, new methodology for travel behaviour survey is currently being prepared in the Czech Republic. The methodology should help to create a unified national database for travel behaviour data.

\section{ACKNOWLEDGMENT}

This paper is funded by the European Union from the European Regional Development Fund, project registration number: M00230, "Gemeinsam mehr erreichen - Společně dosáhneme více".

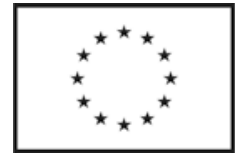

EUROPEAN UNION

EUROPEAN REGIONAL DEVELOPMENT FUND INVESTING IN YOUR FUTURE

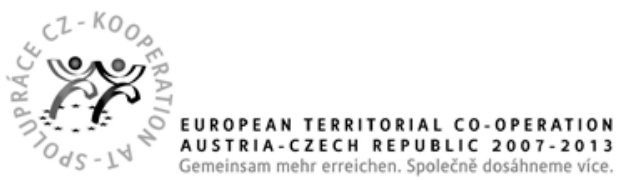

This paper was produced thanks to the institutional support for the long-term conceptual research institute development. 


\section{REFERENCES}

Braun Kohlová, M., Škopková, H., Urban, J., 2007. Analýza každodenního dopravního chování dospélého městského obyvatelstva a nástroje regulace dopravy: Sběr existujících dat o dopravním chování 1.2 k projektu MD24/2006-430-OPI/3 z OP “Infrastruktura" Priorita 2 (2.4) [online]. Praha: Univerzita Karlova v Praze, Centrum pro otázky životního prostředí [cited 2014-05-26]. 20 p. (in Czech)

Cinzia, C., 2010. Automobile ownership model [online]. The National Centre for Smart Growth Research and Education at the University of Maryland [cited 2014-05-22]. Retrieved from: http://smartgrowth.umd.edu/assets/tprg/a1.pdf

de Jong, G., Fox, J., Pieters, M., Daly, A.J., Smith, R., 2004. A comparison of car ownership models. Transport Reviews [online]. 24 (4), pp. 397-408 [cited 2014-05-26]. ISSN 14645327. Retrieved from: http://eprints.whiterose.ac.uk/2467/2/pITS2116A_comparison_of_car_ownership_modelsv4.pdf?origin=publication_detail

Fellendorf, M., Herry, M., Karmasin, H., Klementschitz, R., Kohla, B., Meschik, M., Rehrl, K., Reiter, T., Sammer, G., Schneider, C., Sedlacek, N., Tomschy, R., Wolf, E., 2011. KOMOD - Konzeptstudie Mobilitätsdaten Österreichs: Handbuch für Mobilitätserhebungen.

Follmer, R., Gruschwitz, D., Jesske, B., Quandt, S., Nobis, C., Köhler, K., 2010. Mobilität in Deutschland 2008 - Tabellenband [online]. Bonn: Infas Institut für angewandte Sozialwissenschaft GmbH; Berlin: Deutsches Zentrum für Luft- und Raumfahrt e.V. Institut für Verkehrsforschung [cited 2014-05-22]. Retrieved from:

http://www.mobilitaet-in-deutschland.de/pdf/MiD2008_Tabellenband.pdf

Institut für Verkehrs- und Infrastrukturforschung GmbH, 2009. The New KONTIV Design [online]. [cited 2014-05-27]. Retrieved from:

http://www.socialdata.de/info/KONTIV_engl.pdf

Karasmaa, N., 2003. The Transferability of Travel Demand Models: An analysis of transfer methods, data quality and model estimation. Dissertation paper [online]. Helsinki: Helsinki University of Technology, p. 3 [cited 2014-05-27]. Retrieved from: http://lib.tkk.fi/Diss/2003/isbn9512268574/isbn9512268574.pdf

Mohammadian, A., Zhang, Y., 2007. Investigating the Transferability of National Household Travel Survey Data. In TRB Conference, Washington, D.C., USA, 2007 [online], p. 13 [cited 2014-05-22]. Retrieved from:

http://onlinepubs.trb.org/onlinepubs/archive/committees/AB000/1/07-2030.pdf

Schönfelder, S., Axhausen, K.W., 2010. Urban Rhythms and Travel Behavior. MPG Books Group UK. ISBN 97807546751150.

Stopher, P.R., Greaves, S.P., Xu, M., 2004. Using Nationwide Household Travel Data for Simulating Metropolitan Area Household Travel Data. In TRB Conference, Washington, D.C., USA, 2004 [online]. [cited 2014-05-26]. Retrieved from: http://onlinepubs.trb.org/onlinepubs/archive/conferences/nhts/Xu.pdf 
Timur, 2014 [online]. Týmová iniciativa pro místní udržitelný rozvoj, o. p. s. [cited 2014-0526]. Retrieved from:

http://www.timur.cz/indikatory/mobilita-a-mistni-preprava-cestujicich-2.html (in Czech)

U.S. DOT Volpe National Transportation Systems Center, 2005. Summary Report for the Peer Exchange on Data Transferability: TRB Committees ABJ30, ADB10 and ABJ10 [online]. Washington, D.C., 2005 [cited 2014-05-26]. Retrieved from:

http://www.edthefed.com/xferability/articles/tmip_data_transferability_peer.pdf

Vachtl, M., Melzer, Z., Němec, T., Urbánková, P., Kokeš, O., Dytrych, J., 2012. Dopravní sektorová strategie 2. fáze - Kniha 2 Strategický dopravni model ČR [online], pp.15 [cited 2014-05-26]. Retrieved from: http://www.dopravnistrategie.cz/images/projekt/kestazeni/Kniha2-SV121116CS.pdf (in Czech)

Yu, H., Shaw, S.L., 2004. Representing and Visualizing Travel Diary Data: A Spatiotemporal GIS Approach. In ESRI International User Conference, San Diego, CA, USA, 2004 [online]. [cited 2014-05-26]. Retrieved from:

http://proceedings.esri.com/library/userconf/proc04/docs/pap1258.pdf 